\title{
MILK Symposium Introduction: Dairy production in developing countries*
}

\author{
Adegbola T. Adesogan ${ }^{1,2}+$ ๑ and Geoffrey E. Dahl ${ }^{1,2}$ (1) \\ ${ }^{1}$ Department of Animal Sciences, University of Florida, Gainesville 32611 \\ ${ }^{2}$ Feed the Future Innovation Lab for Livestock Systems, University of Florida, Gainesville 32611
}

\begin{abstract}
In low- and middle-income countries (LMICs), dairy production is highly valued, and demand for milk is projected to continue to increase markedly over the next few decades. This presents a tremendous opportunity to improve the nutrition, health, incomes, and livelihoods of millions of people with the high-quality protein and bioavailable micronutrients in dairy products. However, low dairy consumption levels, due to low affordability, accessibility, and availability, still typify several LMICs. This is caused by inadequate feeding, management, and genetics; poor transport, cooling, and processing infrastructure; unconducive policy environments; and sociocultural and demographic factors. Strategies to address some of these factors were presented at the MILK Symposium hosted by the Feed the Future Innovation Lab for Livestock Systems during the 2019 American Dairy Science Association Annual Meeting. The papers presented are full manuscripts in this Special Issue of the Journal of Dairy Science. They address the importance of dairy products for human health, strategies to address feed, management, health, and food safety challenges in dairy production systems, and sustainability of dairy production in LMICs. They collectively show how strategic interventions can lead to marked improvements in dairy production in developing countries. These will ultimately contribute to meeting the growing global demand for milk and to achievement of the United Nations Sustainable Development Goals. Key words: milk production, food security, malnutrition, economic development
\end{abstract}

\section{INTRODUCTION}

Despite the association of dairy production with various health benefits (Thorning et al., 2016; Bhupathi et al., 2020) and their inadequate consumption by most

\footnotetext{
Received February 4, 2020.

Accepted April 1, 2020.

*Presented as part of the MILK Symposium: Improving Milk Production, Quality, and Safety in Developing Countries at the ADSA Annual Meeting, Cincinnati, Ohio, June 2019.

†Corresponding author: adesogan@ufl.edu
}

Americans (USHHS-USDA, 2015), public concerns about dairy production and consumption in the United States and other high-income countries have led to recent increases in the availability of plant-based alternatives. In contrast, in many low- and middle-income countries (LMICs), dairy production is highly valued, and demand for milk is projected to continue to increase markedly over the next few decades. In fact, the global demand for milk is expected to increase by $35 \%$ by 2030 , driven largely by growth demand in Asia in particular, as well as Africa and Latin America (Figure 1 ; IFCN, 2018). These increases are due to urbanization, increasing education and incomes, and population growth (Bruinsma, 2003; WHO, 2013). The growing demand for dairy products in LMICs presents a tremendous opportunity to use dairying to improve the nutrition, health, incomes, and livelihoods of millions of people. Yet, there is a much more urgent imperative for increased consumption of dairy products in the LMICs. Dairy products are needed to enrich the typically starch-based diets of 800 million low-income people, thereby reducing the high prevalence $(>30 \%)$ of stunting (stunted physical and cognitive development) in many African and Asian populations (UNICEF/WHO/ World Bank, 2018). Stunting, a widely used measure of malnutrition, is associated with poor growth, lower cognitive development (as shown by lower test and intelligent quotient scores), increased susceptibility to chronic diseases such as obesity and diabetes, lower lifelong productivity, and lower economic productivity of nations (Black et al., 2013; Prendergast and Humphrey, 2014). Milk and other dairy products are vital sources of high-quality protein as well as natural and bioavailable forms of micronutrients that are important for preventing stunting, including vitamin $\mathrm{A}$, vitamin $\mathrm{B}_{12}$, iron, iodine, zinc, folic acid and choline, and several others including thiamine (vitamin $\mathrm{B}_{1}$ ), riboflavin (vitamin $\mathrm{B}_{2}$ ), niacin (vitamin $\mathrm{B}_{3}$ ), pantothenic acid (vitamin $\mathrm{B}_{5}$ ), vitamin $\mathrm{D}_{3}$, vitamin $\mathrm{B}_{6}$, calcium, phosphorus, selenium, and potassium (Dror and Allen, 2011, 2018; USHHS-USDA, 2015; Górska-Warsewicz et al., 2019). Although some studies have associated consumption of milk and dairy products with negative health outcomes such as cardiovascular disease, others have noted that 


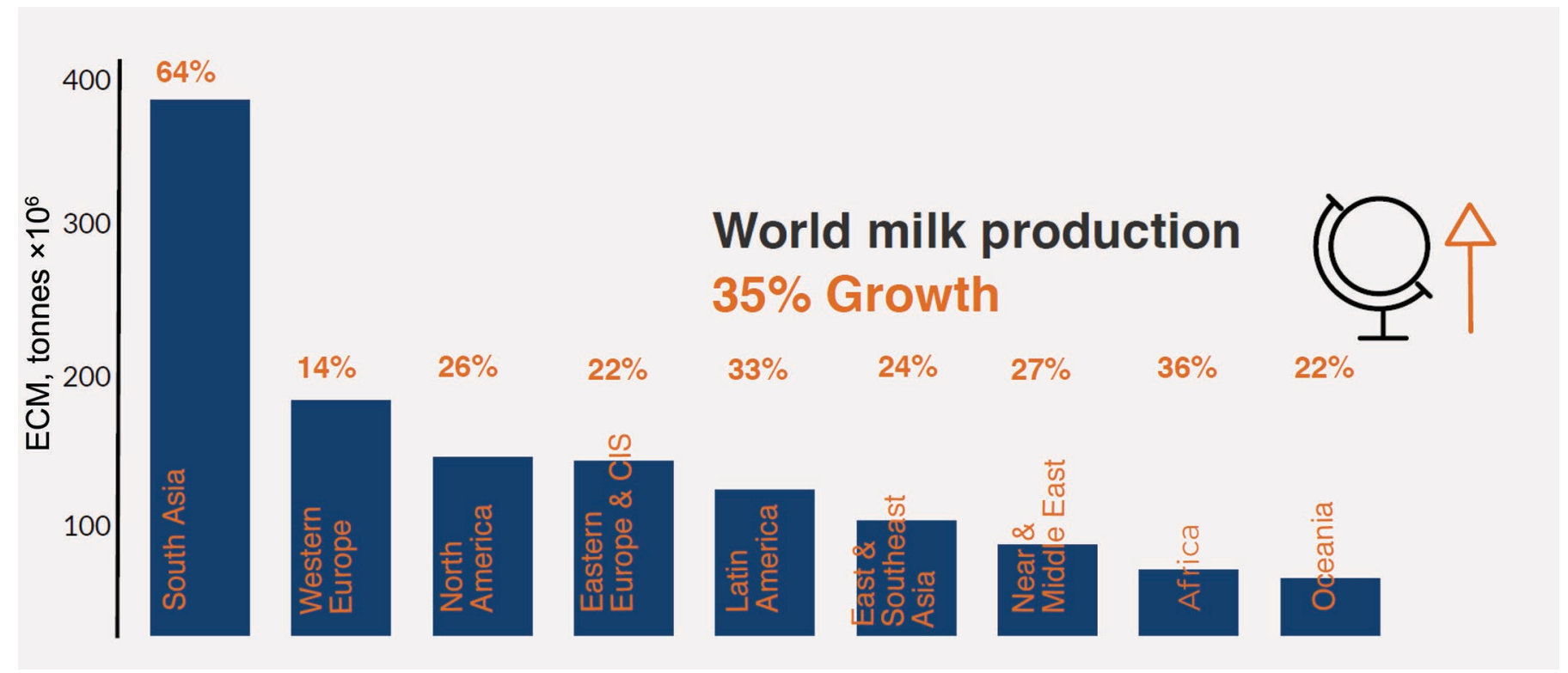

Figure 1. Projected volumes of milk (ECM) that will be produced by region in 2030 and percentage increase over 2017 levels (IFCN, 2018). CIS = Commonwealth of Independent States: Bulgaria, Estonia, Latvia, Lithuania, Romania, Russia, Ukraine.

such associations are unfounded (Fekete et al., 2013). This is because milk and dairy products contain important bioactive factors with various health benefits that counter the potential negative effects, including antioxidants, minerals, peptides, and probiotic bacteria (Fekete et al., 2013; Górska-Warsewicz et al., 2019).

Dairy production also plays a vital role in economic development and sustainability of several LMICs, where it provides critically important contributions to nutrient cycling, plays a crucial role in income generation and poverty alleviation, and serves as a vital source of manure for crop production and cooking fuel and women's empowerment. Therefore, countries such as India, Ethiopia, Nepal, Rwanda, and Kenya have prioritized improvement of their dairy industries. For instance, implementation of the White Revolution program and other dairy development programs in India increased milk production by $400 \%$ from 1968/1969 to $2003 / 2004$, and transformed the country from a place with an acute milk shortage to become the world's top dairy producer, accounting for about $16 \%$ of total global milk production in 2013 (Kurien, 2007; Ohlan, 2013; Deka et al., 2015). Currently, milk contributes close to one-third of the gross income of rural households in India, and the dairy industry contributes most of the $4 \%$ livestock sector contribution to gross domestic product (GDP) and 28\% to agricultural GDP (AIR, 2018; Mondal, 2019). This places dairying at the front of the Indian government's commitment to double farmers' incomes by 2022 (AIR, 2018; MAFW, 2018). Growth in dairying in Kenya has transformed it to become the largest agricultural subsector, contributing $4 \%$ to GDP (IGAD, 2013). The Rwandan government promotes dairying as a key poverty alleviation strategy through its "Girinka" (one cow per poor family) program. The Girinka program has led to increased incomes, increased crop yields and soil fertility (Kim et al., 2011), improved nutrition, and improved health by increasing affordability of health insurance, and it has made entrepreneurs out of numerous previously malnourished citizens (Ezeanya, 2014).

Globally, dairy consumption levels in LMICs are highly variable. Notoriously low levels of consumption typify the Democratic Republic of Congo, where the average consumption is $1 \mathrm{~kg} /$ person per year, which is a small fraction of the recommendations of the World Health Organization (175 kg/person per year) or Food and Agriculture Organization (200 kg/person per year) and an even smaller fraction of that consumed $(>300 \mathrm{~kg} /$ person per year) in Sweden and Finland (FAO, 2019). Per capita milk consumption is high $(>150 \mathrm{~kg} /$ person per year) in Argentina, Armenia, Australia, Costa Rica, Europe, Israel, Kyrgyzstan, North America, and Pakistan; moderate (30 to $150 \mathrm{~kg}$ /person per year) in India, Islamic Republic of Iran, Japan, Kenya, Mexico, Mongolia, New Zealand, North and Southern Africa, most of the Near East, and most of Latin America and the Caribbean; and low $(<30 \mathrm{~kg} /$ person per year $)$ in Vietnam, Senegal, most of Central Africa, and most of East and Southeast Asia (FAO, 2019).

The low consumption of dairy products in LMICs in East and Southeast Asia as well as sub-Saharan Africa 
(excluding South Africa) is partly due to low availability, affordability, and accessibility of dairy products (McDowell, 1981; Kapaj, 2018). Underlying issues affecting affordability and availability include shortage of quality feed and adequate land, inadequate cow and milking management and housing facilities, small herd sizes, prevalence of low-genetic-merit breeds, weak disease prevention and control systems, poor transport, cooling and storage infrastructure, weak markets, and unconducive policy environments (McDowell, 1981; Kapaj, 2018).

More salient contributors to the low consumption levels include sociocultural and demographic factors such as food taboos, sex, education level (Kapaj, 2018), and religious fasting (e.g., abstinence from animal-source food consumption for up $240 \mathrm{~d} / \mathrm{yr}$ in Ethiopia). Additional factors include the low productivity of dairy cows due to retention of unproductive animals in the herd for religious reasons in India and Nepal (Bhaskaran, 1996). Further, weak regulatory systems have fostered concerns about contamination of dairy products with pathogens, toxins (particularly aflatoxin), and chemicals such as pesticide residues and antibiotics (Grace et al., 2020). In addition, high volumes of variable quality and sometimes adulterated milk sold through informal marketing channels can account for up to $70 \%$ of the national production in some LMICs (Sinja et al., 2006; Grace et al., 2020).

The foregoing highlights the importance of increasing the productivity, affordability, accessibility, and safety of dairy products in LMICs. The papers presented in this special issue of the Journal of Dairy Science outline different strategies to improve these factors. These papers were presented at the MILK Symposium during the 2019 annual meeting of the American Dairy Science Association ${ }^{\circledR}$ in Cincinnati, Ohio, which was sponsored by the Feed the Future Innovation Lab for Livestock Systems (Gainesville, FL). The vision of the US Agency for International Development (USAID) and Bill and Melinda Gates-funded Feed the Future Innovation Lab for Livestock Systems at the University of Florida is to sustainably intensify livestock production to improve the nutrition, health, incomes, and livelihoods of the poor. Several of its 45 projects focus on improving dairy production in developing countries. In partnership with the International Livestock Research Institute (Nairobi, Kenya), several US universities, and over 40 foreign partners, the Innovation Lab manages and implements research for development projects in Kenya, Uganda, Nepal, Cambodia, Burkina Faso, Niger, Rwanda, and Ethiopia. A complementary project with similar dairy industry improvement goals at the University of Florida works in Sri Lanka.
This special issue begins with a general overview about the nutritional importance of milk (Givens, 2020) followed by several Innovation Lab and related project papers on strategies to improve dairy production and quality, milk safety, and milk consumption (Amenu et al., 2020; De Vries et al., 2020; Grace et al., 2020; Miller et al., 2020; Ndahetuye et al., 2020; Sah et al., 2020; Vyas et al., 2020). The special issue concludes with a paper on the sustainability of milk production in LMICs (Tricarico et al., 2020). The papers collectively show how strategic interventions can lead to marked improvements in dairy production in developing countries. These will ultimately contribute to meeting the growing global demand for milk and to achievement of the United Nations Sustainable Development Goals related to alleviation of hunger and poverty, improvement of education and employment, and environmental stewardship (United Nations, 2018).

\section{ACKNOWLEDGMENTS}

This work was funded in whole or part by the United States Agency for International Development (USAID, Washington, DC) Bureau for Food Security under Agreement \# AID-OAA-L-15-00003 as part of Feed the Future Innovation Lab for Livestock Systems (Gainesville, FL). Any opinions, findings, conclusions, or recommendations expressed here are those of the authors alone. The authors have not stated any conflicts of interest.

\section{REFERENCES}

AIR (All India Radio). 2018. Contribution of dairy farming in the economy. Accessed May 28, 2020. https://iasbaba.com/2018/12/ all-india-radio-air-ias-upsc-contribution-of-dairy-farming-in-the -economy/.

Amenu, K., G. Agga, A. Kumbe, A. Shibiru, H. Wodajo, W. Tiki, O. Kerro Dego, B. Wieland, D. Grace, and S. Alonso. 2020. MILK Symposium review: Community-tailored training to improve the knowledge, attitudes, and practices of women regarding hygienic milk production and handling in Borana pastoral area of southern Ethiopia. J. Dairy Sci. 103:9748-9757. https://doi.org/10.3168/jds .2020-18292.

Bhaskaran, S. 1996. Culture's consequences: Dairy market opportunities in India. Mark. Bull. 7:39-50. Accessed May 28, 2020. http:// marketing-bulletin.massey.ac.nz.

Bhupathi, V., M. Mazariegos, J. B. Cruz Rodriguez, and A. Deoker. 2020. Dairy intake and risk of cardiovascular disease. Curr. Cardiol. Rep. 22:11. https://doi.org/10.1007/s11886-020-1263-0.

Black, R. E., C. Victora, S. Walker, Z. Bhutta, P. Christian, M. De Onis, M. Ezzati, S. Grantham-McGregor, J. Katz, R. Martorell, and R. Uauy. 2013. Maternal and child undernutrition and overweight in low-income and middle-income countries. Lancet 382:427-451. https://doi.org/10.1016/S0140-6736(13)60937-X.

Bruinsma, J. 2003. World agriculture: Towards 2015/2030. An FAO Perspective. Earthscan, Food and Agriculture Organization of the United Nations, Rome, Italy. Accessed May 28, 2020. http://www .fao.org/3/a-y4252e.pdf. 
Deka, R., J. Lindahl, T. Randolph, and D. Grace. 2015. The White Revolution in India: The end or a new beginning? Proc. Agric.4D 2015 Conf., Uppsala, Sweden. International Livestock Research Institute, Nairobi, Kenya. Accessed May 28, 2020. https://www .slideshare.net/ILRI/white-revolution-in-india.

De Vries, A., K. Kaylegian, and G. E. Dahl. 2020. MILK Symposium review: Improving the productivity, quality, and safety of milk in Rwanda and Nepal. J. Dairy Sci. 103:9758-9773. https://doi.org/ $10.3168 /$ jds.2020-18304.

Dror, D. K., and L. H. Allen. 2011. The importance of milk and other animal-source foods for children in low-income countries. Food Nutr. Bull. 32:227-243. https://doi.org/10.1177/156482651103200307.

Dror, D. K., and L. H. Allen. 2018. Overview of nutrients in human milk. Adv. Nutr. 9(Suppl_1):278S-294S. https://doi.org/10.1093/ advances/nmy022.

Ezeanya, C. 2014. Indigenous knowledge, economic empowerment and entrepreneurship in Rwanda: The Girinka approach. J. Pan Afr. Stud. 6:241-263.

FAO. 2019. Food and Agricultural Organization of the United Nations. Gateway to dairy production and products. Accessed May 28, 2020. http://www.fao.org/dairy-production-products/products/ en/.

Fekete, A. A., D. I. Givens, and J. A. Lovesgrove. 2013. The impact of milk proteins and peptides on blood pressure and vascular function: A review of evidence from human intervention studies. Nutr. Res. Rev. 26:177-190.

Givens, D. I. 2020. MILK Symposium review: The importance of milk and dairy foods in the diets of infants, adolescents, pregnant women, adults, and the elderly. J. Dairy Sci. 103:9681-9699. https:// doi.org/10.3168/jds.2020-18296.

Górska-Warsewicz, H., K. Rejman, W. Laskowski, and M. Czeczotko. 2019. Milk and dairy products and their nutritional contribution to the average polish diet. Nutrients 11:1771. https://doi.org/10 $.3390 /$ nu11081771.

Grace, D., F. Wu, and A. Havelaar. 2020. MILK Symposium review: Foodborne diseases from milk and milk products in developing countries-Review of causes and health and economic implications. J. Dairy Sci. 103:9715-9729. https://doi.org/10.3168/jds .2020-18323.

IGAD. 2013. The contribution of livestock to the Kenyan economy. Centre for Pastoral Areas and Livestock Development (ICPALD) Policy Brief No. 4/CLE/8/2013. Accessed May 28, 2020. http: //igad.int/attachments/714_The\%20Contribution \%20of\%20 Livestock\%20to\%20the\%20Kenyan\%20Economy.pdf.

International Farm Comparison Network. 2018. Dairy Outlook 2030. Accessed May 28, 2020. https://ifcndairy.org/wp-content/ uploads/2018/06/IFCN-Dairy-Outlook-2030-Brochure.pdf.

Kapaj, A. 2018. Factors that influence milk consumption world trends and facts. Eur. J. Bus. Econ. Account. 6:14.

Kim, S. K., K. Tiessen, A. Beeche, J. Mukankurunziza, and A. Kamatari. 2011. Cattle manure management in Rwanda-A case of Girinka cow beneficiaries in the district of Ngoma. Rwanda J. 24:39-48.

Kurien, V. 2007. India's milk revolution: Investing in rural producer organizations. Pages 27-67 in Ending Poverty in South Asia: Ideas That Work. D. Narayan and E. Glinskaya, ed. The World Bank, Washington, DC.

McDowell, R. E. 1981. Limitations for dairy production in developing countries. J. Dairy Sci. 64:2463-2475. https://doi.org/10.3168/jds .S0022-0302(81)82871-8.

MAFW (Ministry of Agriculture and Farmers Welfare). 2018. Production enhancement through productivity gains. Report of the committee for doubling farmers' income. Volume VIII. Accessed May 28, 2020. http://farmer.gov.in/imagedefault/DFI/DFI\%20 Vol-8A.pdf.

Miller, L. C., S. Neupane, N. Joshi, and M. Lohani. 2020. MILK Symposium review: Milk consumption is associated with better height and weight in rural Nepali children over 60 months of age and better head circumference in children 24 to 60 months of age. J. Dairy Sci. 103:9700-9714. https://doi.org/10.3168/jds.2020-18289.

Mondal, P. 2019. Development of dairy industry in India. Accessed May 28, 2020. http://www.yourarticlelibrary.com/dairy-farm -management/development-of-dairy-industry-in-india/35570.

Ndahetuye, J. B., K. Artursson, R. Båge, A. Ingabire, C. Karege, J. Djangwani, A.-K. Nyman, M. P. Ongol, M. Tukei, and Y. Perrson. 2020. MILK Symposium review: Microbiological quality and safety of milk from farm to milk collection centers in Rwanda. J. Dairy Sci. 103:9730-9739. https://doi.org/10.3168/jds.2020-18302.

Ohlan, R. 2013. Efficiency and total factor productivity growth in Indian dairy sector. J. Integr. Agric. 52:51-77.

Prendergast, A. J., and J. H. Humphrey., 2014. The stunting syndrome in developing countries. Paediatr. Int. Child Health 34:250-265. https://doi.org/10.1179/2046905514Y.0000000158.

Sah, K., P. Karki, R. D. Shrestha, A. Sigdel, A. T. Adesogan, and G. E. Dahl. 2020. MILK Symposium review: Improving control of mastitis in dairy animals in Nepal. J. Dairy Sci. 103:9740-9747. https://doi.org/10.3168/jds.2020-18314.

Sinja, J., L. Njoroge, H. Mbaya, H. Magara, E. Mwangi, I. Baltenweck, D. Romney, and A. Omore. 2006. Milk Market Access for Smallholders: A Case of Informal Milk Trader groups in Kenya. Research Workshop on Collective Action and Market Access for Smallholders. Cali, Colombia. Accessed May 28, 2020. http://www .capri.cgiar.org/files/pdf/CA-Market_Sinja-J.pdf.

Thorning, T. K., A. Raben, T. Tholstrup, S. S. Soedamah-Muthu, I. Givens, and A. Astrup. 2016. Milk and dairy products: Good or bad for human health? An assessment of the totality of scientific evidence. Food Nutr. Res. 60:32527. https://doi.org/10.3402/fnr .v60.32527.

Tricarico, J., E. Kebreab, and M. Wattiaux. 2020. MILK Symposium review: Sustainability of dairy production and consumption in low income countries with emphasis on productivity and environmental impact. J. Dairy Sci. 103:9791-9802. https://doi.org/10.3168/ jds.2020-18269.

UNICEF/WHO/World Bank. 2017. Global database on child growth and malnutrition. Joint child malnutrition estimates-Levels and trends. Accessed May 28, 2020. http://www.who.int/nutgrowthdb/ estimates2016/en/.

UNICEF/WHO/World Bank. 2018. Joint child malnutrition estimates 2018 edition. Accessed May 28, 2020. https://www.who.int/ nutgrowthdb/2018-jme-brochure.pdf.

United Nations. 2018. The Sustainable Development Goals Report 2018. UN Statistics Division. Accessed May 28, 2020. https:// unstats.un.org/sdgs/report/2018/overview/.

USHHS-USDA (US Department of Health and Human Services and US Department of Agriculture). 2015. 2015-2020 Dietary Guidelines for Americans, 8th ed. USDA, Washington, DC. Accessed May 28, 2020. https://health.gov/our-work/food-nutrition/2015 -2020-dietary-guidelines.

Vyas, D., N. Corwin, J. Bromfield, L. Pradeep, M. Krause, and G. E. Dahl. 2020. MILK Symposium review: Identifying constraints, opportunities, and best practices for improving milk production in market-oriented dairy farms in Sri Lanka. J. Dairy Sci. 103:97749790. https://doi.org/10.3168/jds.2020-18305.

WHO (World Health Organization). 2013. Global and regional food consumption patterns and trends. Accessed May 28, 2020. https: //www.who.int/nutrition/topics/3_foodconsumption/ en/index1. html.

\section{ORCIDS}

Adegbola T. Adesogan () https://orcid.org/0000-0003-1020-7526

Geoffrey E. Dahl $\odot$ https://orcid.org/0000-0002-2182-6317 